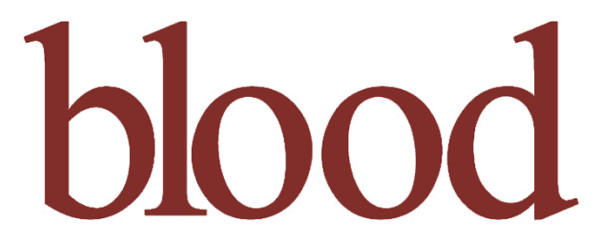

2009 113: 755-764

Prepublished online Sep 29, 2008:

doi:10.1182/blood-2008-06-161794

\title{
Critical role of scavenger receptor-Blexpressing bone marrowderived endothelial progenitor cells in the attenuation of allograft vasculopathy after human apo A-I transfer
}

Yingmei Feng, Miranda van Eck, Eline Van Craeyveld, Frank Jacobs, Vincent Carlier, Sophie Van Linthout, Martin Erdel, Marc Tjwa and Bart De Geest

Updated information and services can be found at:

http://bloodjournal.hematologylibrary.org/cgi/content/full/113/3/755

Articles on similar topics may be found in the following Blood collections:

Transplantation (1438 articles)

Vascular Biology (80 articles)

Information about reproducing this article in parts or in its entirety may be found online at:

http://bloodjournal.hematologylibrary.org/misc/rights.dt|\#repub_requests

Information about ordering reprints may be found online at:

http://bloodjournal.hematologylibrary.org/misc/rights.dtl\#reprints

Information about subscriptions and ASH membership may be found online at:

http://bloodjournal.hematologylibrary.org/subscriptions/index.dtl

Blood (print ISSN 0006-4971, online ISSN 1528-0020), is published semimonthly by the American Society of Hematology, 1900 M St, NW, Suite 200, Washington DC 20036.

Copyright 2007 by The American Society of Hematology; all rights reserved.

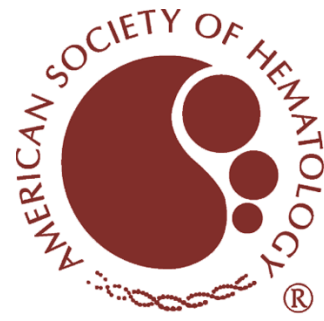




\title{
Critical role of scavenger receptor-BI-expressing bone marrow-derived endothelial progenitor cells in the attenuation of allograft vasculopathy after human apo A-I transfer
}

\author{
Yingmei Feng, ${ }^{1}$ Miranda van Eck, ${ }^{2}$ Eline Van Craeyveld, ${ }^{1}$ Frank Jacobs, ${ }^{1}$ Vincent Carlier,,${ }^{1}$ Sophie Van Linthout, ${ }^{3}$ \\ Martin Erdel, ${ }^{4}$ Marc Tjwa, ${ }^{5}$ and Bart De Geest ${ }^{1}$ \\ ${ }^{1}$ Center for Molecular and Vascular Biology, University of Leuven, Leuven, Belgium; 2Division of Biopharmaceutics, Leiden/Amsterdam Center for Drug \\ Research, Gorlaeus Laboratories, Leiden University, Leiden, The Netherlands; ${ }^{3}$ Department of Cardiology, Charité University-Medicine Berlin, Berlin, Germany; \\ ${ }^{4}$ Division of Clinical Genetics, Medical University of Innsbruck, Innsbruck, Austria; and ${ }^{5}$ Vesalius Research Center, Flanders Institute for Biotechnology (VIB), \\ University of Leuven, Leuven, Belgium and Leibniz AG, Center for Molecular Medicine, Institute of Cardiovascular Regeneration, University of Frankfurt, \\ Frankfurt, Germany
}

\begin{abstract}
Allograft vasculopathy is the leading cause of death in patients with heart transplantation. Accelerated endothelial regeneration mediated by enhanced endothelial progenitor cell (EPC) incorporation may attenuate the development of allograft vasculopathy. We investigated the hypothesis that modulation of EPC biology and attenuation of allograft vasculopathy by increased high-density lipoprotein cholesterol after human apo A-I (AdA-I) transfer requires scavenger receptor (SR)-BI expression in bone marrow-
\end{abstract}

derived EPCs. After AdA-I transfer, the number of circulating EPCs increased 2.0 -fold $(P<.001)$ at different time points in C57BL/6 mice transplanted with SR$\mathrm{BI}^{+/+}$bone marrow but remained unaltered in mice with $\mathrm{SR}-\mathrm{BI}^{-I-}$ bone marrow. The effect of high-density lipoprotein on EPC migration in vitro requires signaling via SR-BI and extracellular signalregulated kinases and is dependent on increased nitric oxide (NO) production in EPCs. Human apo A-I transfer 2 weeks before paratopic artery transplantation reduced intimal area at day 213.7 -fold $(P<.001)$ in mice with $\mathrm{SR}-\mathrm{BI}^{+/+}$bone marrow but had no effect in mice with SR-BI-I- bone marrow. AdA-I transfer potently stimulated EPC incorporation and accelerated endothelial regeneration in chimeric $\mathrm{SR}-\mathrm{BI}^{+/+}$mice but not in chimeric SR-BI ${ }^{-1-}$ mice. In conclusion, human apo A-I transfer accelerates endothelial regeneration mediated via SR-BI expressing bone marrow-derived EPCs, thereby preventing allograft vasculopathy. (Blood. 2009;113:755-764)

\section{Introduction}

Cardiac allograft vasculopathy is the leading cause of late heart failure and death after heart transplantation. ${ }^{1,2}$ Transplantation vasculopathy is caused by recognition of major histocompatibility complex class I and class II antigens on the endothelium of the allograft by recipient $\mathrm{T}$ lymphocytes. This initiates an inflammatory cascade leading to macrophage activation and proliferation of smooth muscle cells. ${ }^{3}$ Denuding endothelial injury in allografts occurs as a consequence of peritransplantation ischemia/reperfusion injury and of cellular immunity. Because the endothelium regulates vascular tone, inflammation, smooth muscle cell proliferation, and thrombosis, ${ }^{4}$ restoration of endothelial integrity and function is pivotal to attenuate the development of allograft vasculopathy. ${ }^{5}$

Disruption of the endothelial lining resulting from endothelial cell apoptosis can be restored by proliferation of adjacent endothelial cells but also by incorporation of circulating bone marrowderived endothelial progenitor cells (EPCs). ${ }^{6-9} \mathrm{Hu}$ et $\mathrm{al}^{10}$ have demonstrated that EPCs contribute to endothelial regeneration and to microvessel formation in allografts. Recently, we have shown that increased high-density lipoprotein (HDL) cholesterol levels after hepatocyte-directed human apo A-I transfer in C57BL/6 apo $\mathrm{E}^{-1-}$ mice increase circulating EPC number, enhance the incorporation of bone marrow-derived EPCs into the injured endothelium, and reduce neointima formation in a murine model of transplantation arteriosclerosis. ${ }^{11}$ Evaluation of EPC function in vitro showed that addition of HDL improved EPC adhesion, migration, and invasion. ${ }^{11}$ This prior study suggests that attenuation of allograft vasculopathy after human apo A-I transfer is mediated by enhanced EPC incorporation into allografts. However, because HDL has pleiotropic effects on lipoprotein metabolism and vascular biology, the mechanistic link between the effects of HDL on EPC biology and on allograft vasculopathy remains uncertain. A more stringent experimental approach that dissociates effects of HDL on EPCs from other actions of HDL is required to investigate the role of enhanced EPC number and function in the attenuation of allograft vasculopathy after human apo A-I transfer.

Scavenger receptor (SR)-BI is an HDL receptor that plays a critical role in reverse cholesterol transport by mediating selective lipid uptake from HDL particles. ${ }^{12,13}$ SR-BI is expressed in hepatocytes, ${ }^{12}$ steroidogenic tissues, ${ }^{12}$ Kupffer cells, ${ }^{14}$ and macrophages ${ }^{15}$ but also in endothelial cells. ${ }^{16} \mathrm{HDL}$ stimulates endothelial cell migration in vitro via SR-BI. ${ }^{16}$ In addition, the effects of HDL on endothelium-dependent vasoreactivity appear to depend on the binding of HDL to SR-BI and subsequent stimulation of NO formation. ${ }^{17}$ Whether SR-BI plays a role in EPC biology has not been evaluated before. In the current study, we investigated the
Submitted June 6, 2008; accepted September 9, 2008. Prepublished online as Blood First Edition paper, September 29, 2008; DOI 10.1182/blood-2008-06161794.

The online version of this article contains a data supplement.
The publication costs of this article were defrayed in part by page charge payment. Therefore, and solely to indicate this fact, this article is hereby marked "advertisement" in accordance with 18 USC section 1734.

(C) 2009 by The American Society of Hematology 
hypothesis that modulation of EPC biology by increased HDL cholesterol after hepatocyte-directed human apo A-I transfer requires SR-BI expression on bone marrow-derived EPCs. If this hypothesis is correct, bone marrow transplantation of SR-BIdeficient bone marrow may abrogate the effect of HDL on bone marrow-derived EPCs and at the same time leave other effects of HDL intact. To investigate whether the inhibition of allograft vasculopathy by human apo A-I transfer requires SR-BI expression in bone marrow cells, transplantation of bone marrow obtained from SR-BI ${ }^{+/+}$or SR-BI ${ }^{-/-}$donor mice was performed in C57BL/6 mice before gene transfer or saline injection and artery transplantation. We show for the first time that enhanced EPC number, function and incorporation after human apo A-I transfer is strictly dependent on SR-BI expression in bone marrow-derived EPCs. Human apo A-I transfer accelerates EPC-mediated endothelial regeneration in allografts and thereby prevents the development of transplantation arteriosclerosis in chimeric SR-BI ${ }^{+/+}$mice but not in chimeric SR-BI ${ }^{-1-}$ mice. The effect of HDL on EPC biology requires signaling via SR-BI and extracellular signal-regulated kinases (ERK) and is dependent on enhanced NO production. Taken together, the results of the current study indicate that increased EPC number, function, and incorporation induced by therapeutic HDL levels after human apo A-I transfer is probably the main effector of the beneficial effects of increased HDL cholesterol on allograft vasculopathy.

\section{Methods}

\section{Animals}

All experimental procedures were approved by the ethical committee for animal experimentation of the Katholieke Universiteit Leuven. The investigation conforms to the Guide for the Care and Use of Laboratory Animals published by the US National Institutes of Health (Publication No. 85-23, revised 1996). C57BL/6 $\left(\mathrm{H} 2^{\mathrm{b}}\right)$ and BALB/c $\left(\mathrm{H} 2^{\mathrm{d}}\right)$ mice were obtained from the specific pathogen-free facility of the Center for Molecular and Vascular Biology. SR-BI ${ }^{-1-}$ mice, originally developed by Rigotti et al, ${ }^{18}$ were backcrossed to the C57BL/6 background at the University of Leiden for 5 generations. Bone marrow cells and spleens obtained from these SR-BI ${ }^{-1-}$ mice were kindly provided by M.v.E. Mice were fed normal chow ad libitum.

\section{Gene transfer and artery transplantations}

Gene transfer was performed with $5 \times 10^{10}$ particles of AdA-I or Adnull at the age of 13 weeks. AdA-I is an E1E3E4-deleted adenoviral vector containing the human $\alpha_{l}$-antitrypsin promoter upstream of the genomic human apo A-I sequence and 4 copies of the human hepatic control region-1. ${ }^{19,20}$ The E1E3E4-deleted control vector Adnull does not contain an expression cassette. ${ }^{20}$ Two weeks after gene transfer or saline injection, a common carotid artery of a female BALB/c donor mouse was transplanted paratopically into the recipient male C57BL/6 mice as described previously. ${ }^{11,21}$ In selected experiments, to determine incorporation of bone marrow-derived EPCs, recipient C57BL/6 mice were female.

\section{Bone marrow transplantations}

C57BL/6 mice were lethally irradiated with $9.5 \mathrm{~Gy}$ at the age of 9 weeks. Transplantation of $3 \times 10^{6}$ bone marrow cells obtained from male SR$\mathrm{BI}^{+/+}$or male SR-BI ${ }^{-/-}$mice was performed 24 hours after irradiation via tail vein injection. Gene transfer and artery transplantation were subsequently performed in recipient mice at the age of 13 and 15 weeks, respectively.

\section{Human apo A-I ELISA}

Human apo A-I levels were determined by sandwich enzyme-linked immunosorbent assay (ELISA) as described previously. ${ }^{22}$

\section{Separation of lipoproteins by gel filtration}

Mouse plasma lipoproteins were fractioned by fast performance liquid chromatography gel filtration of $100 \mu \mathrm{L}$ plasma as described previously. ${ }^{22}$ Cholesterol levels in non-HDL and HDL fractions were determined by Amplex Red Kit (Invitrogen, Carlsbad, CA).

\section{HDL isolation by density gradient ultracentrifugation}

Plasma HDL $(1.063 \mathrm{~g} / \mathrm{mL}<$ density $<1.21 \mathrm{~g} / \mathrm{mL})$ was isolated from plasma of C57BL/6 mice treated with AdA-I vector by density gradient ultracentrifugation in a swing-out rotor as described..$^{11,23}$

\section{FACS}

The number of circulating EPCs or the number of EPCs in bone marrow was determined by quantification of the number of Flk-1 Sca-1 doublepositive cells by fluorescence-activated cell sorter (FACS) as described before. $^{11}$

\section{Evaluation of SR-BI expression by immunocytochemistry}

Murine spleen EPC culture and human EPC culture were performed as described previously. ${ }^{11}$ To study SR-BI expression in EPCs, circulating human mononuclear cells and murine spleen cells were cultured for 4 and 7 days, respectively, and incubated with DiI-acLDL $(6.6 \mu \mathrm{g} / \mathrm{mL}$; Invitrogen) for 4 hours before fixation in $4 \%$ paraformaldehyde. After overnight incubation with a 1:1000 dilution of rabbit anti-mouse SR-BI primary antibody (Abcam, Cambridge, United Kingdom) and subsequent incubation for 1 hour with a horseradish peroxidase-conjugated goat anti-rabbit antibody (Dako Denmark, Glostrup, Denmark) in a 1:100 dilution, a positive signal was detected using the NEL 704 Kit (PerkinElmer Life and Analytical Sciences, Waltham, MA) according to the instructions of the manufacturer. Images were acquired using Zeiss Axiovision 4.6 software on a Zeiss AxioVert 100M microscope equipped with a Zeiss AxioCam MRc5 digital camera at a $20 \times / 0.4$ magnification (Carl Zeiss, Jena, Germany). Post-hoc image analysis was performed using KS300 software (Carl Zeiss). In parallel, cultured murine EPCs from $\mathrm{SR}-\mathrm{BI}^{-/-}$mice were used as a negative control.

\section{Murine bone marrow EPC culture and quantification}

Bone marrow mononuclear cells were isolated from bone marrowtransplanted C57BL/6 mice 21 days after artery transplantation by density gradient centrifugation using Histopaque-1077 (Sigma Chemie, Deisenhofen, Germany) as described. ${ }^{24}$ Immediately after isolation, cells were plated onto fibronectin $(40 \mu \mathrm{g} / \mathrm{mL})$-coated 24 -well plates at a density of $4 \times 10^{6}$ cells/well and cultured in EGM-2MV Bullet Kit medium (Cambrex, East Rutherford, NJ). After 7 days of culture, medium was removed and adhered cells were stained for DiI-acLDL $(6.6 \mu \mathrm{g} / \mathrm{mL}$; Invitrogen) for 4 hours and then fluorescein isothiocyanate (FITC)-labeled isolectin (10 $\mu \mathrm{g} / \mathrm{mL}$; Invitrogen) for 1 hour. The number of EPCs, identified as DiI-acLDL isolectin double-positive cells, per microscopy field was quantified using Zeiss Axiovision 4.6 acquisition software on a Zeiss AxioPlan 2 microscope equipped with a Zeiss AxioCam MRc5 digital camera at a $20 \times / 0.4$ magnification (Carl Zeiss).

\section{EPC migration assay}

EPC migration assay was performed as described before. ${ }^{11}$ Migration was performed in the presence of HDL $(100 \mu \mathrm{g} / \mathrm{mL})$ or an equivalent amount of bovine serum albumin (Roche Diagnostics, Mannheim, Germany). To investigate whether the effect of HDL on EPC migration requires signaling via ERKs and depends on $\mathrm{NO}$, the effect of $\mathrm{HDL}$ on migration of SR-BI ${ }^{+/+}$ EPCs was studied in the presence of the mitogen-activated protein kinase kinase 1 (MEK1) and MEK2 inhibitor U0126 (10 $\mu$ M; Cell Signaling 
Technology, Danvers, MA) and the NO synthase inhibitor $N^{\mathrm{G}}$-monomethylL-arginine (LNMA, $2 \mathrm{mM}$; Sigma Chemie), respectively.

Methods corresponding to EPC experiments are described in Document S1 (available on the Blood website; see the Supplemental Materials link at the top of the online article).

\section{Evaluation of $\mathrm{p}$-ERK expression by Western blot}

After 7 days of culture of bone marrow mononuclear cells obtained from $\mathrm{SR}-\mathrm{BI}^{+/+}$or SR-BI ${ }^{-/-}$mice, $\mathrm{HDL}(100 \mu \mathrm{g} / \mathrm{mL})$ or an equivalent amount of bovine serum albumin was added for 2.5 minutes. Cells were subsequently harvested in lysis buffer $(20 \mathrm{mM}$ Tris, $\mathrm{pH} 7.5,150 \mathrm{mM} \mathrm{NaCl}, 1 \mathrm{mM}$ ethylenediaminetetraacetic acid, $1 \mathrm{mM}$ ethylene glycol-bis- $N, N, N^{\prime}, N^{\prime}$ tetraacetic acid, $1 \%$ Triton, $1 \mathrm{mM}$ sodium vanadate, $1 \times$ PhosSTOP (Roche Diagnostics), and complete proteinase inhibitor; Roche Diagnostics). After separation of the lysate $(50 \mu \mathrm{g}$ per lane) in a $12 \%$ sodium dodecyl sulfate-polyacrylamide gel electrophoresis (SDS-PAGE) system, proteins were transferred to a nitrocellulose membrane (GE Healthcare, Little Chalfont, United Kingdom). After overnight incubation with a 1:1000 dilution of rabbit antimouse p42 (ERK-2)/p44 (ERK-1) ERK or p-p42/pp44 ERK antibodies (Cell Signaling Technology) and subsequent incubation for 1 hour with horseradish peroxidase-labeled goat antirabbit antibodies (Dako Denmark) in a 1:1000 dilution, the membrane was developed using enhanced chemiluminescence detection reagent (GE Healthcare). Films were scanned on an Epson Perfection V700 Photo scanner (Seiko Epson, Nagano, Japan), and p-ERK and ERK levels were quantified using Image $\mathbf{J}$ software (Wayne Rasband, National Institutes of Health, http://www.rsb.info.nih.gov/ij/).

\section{Quantification of NO production}

Nitrite, nitrate, and $S$-nitrosothiol levels $\left(\mathrm{NO}_{\mathrm{x}}\right)$ were quantified as stable oxidative products of $\mathrm{NO}$ in cell supernatant or bone marrow plasma by the Griess method using a Sievers chemiluminescent NO analyzer as previously described. ${ }^{25}$ Negative control values obtained from unconditioned medium were subtracted from the sample values. $\mathrm{NO}_{\mathrm{x}}$ values were normalized to protein concentration in medium or bone marrow plasma.

\section{Histologic analysis}

C57BL/6 artery transplantation recipients were killed for histologic analysis of the allografts 21 days after artery transplantation. Perfusion fixation, tissue processing, and morphometric analysis were performed as described before. ${ }^{11}$

\section{Immunohistochemistry}

Paraffin sections were stained with rat antimouse CD45 (1:100; BD Biosciences, San Jose, CA), rat antimouse Mac-3 (1:50; BD Biosciences), rabbit antihuman CD3 (1:50; Dako), and rat antimouse CD31 (1:500; BD Biosciences) to detect leukocytes, macrophages, T lymphocytes, and endothelial cells, respectively. Images were acquired on a Zeiss AxioPlan 2 microscope at a $20 \times / 0.4$ magnification (Carl Zeiss). Inflammatory cells were quantified in a blinded fashion by computer assisted image analysis using KS300 software (Carl Zeiss). The percentage of leukocytes, macrophages, and T lymphocytes was determined as the ratio of $\mathrm{CD} 45, \mathrm{Mac}-3$, and $\mathrm{CD}^{+}$cells, respectively, in the neointima divided by the total number of cells in the neointima and multiplied by 100 . The absolute number of endothelial cells per section was determined by CD31 immunohistochemistry and quantification via computer assisted image analysis using KS300 software (Carl Zeiss).

In situ hybridization for the murine Y-chromosome-bone marrow transplantations with bone marrow of male $\mathrm{SR}-\mathrm{BI}^{+/+}$or male $\mathrm{SR}-\mathrm{BI}^{-/-}$ bone marrow were performed at the age of 9 weeks in female C57BL/6 recipients. Artery transplantation using common carotid arteries obtained from female BALB/c donors was performed at the age of 15 weeks, 2 weeks after gene transfer or saline injection. To quantify incorporation of EPCs in the allografts, in situ hybridization for the murine Y-chromosome was performed in the laboratory of M.E. essentially as described previously. ${ }^{26,27}$ Briefly, paraffin sections were dewaxed in xylol and permeabilized in $2 \mathrm{mg} / \mathrm{mL}$ pepsin (Sigma Chemie) in $0.1 \mathrm{M} \mathrm{HCl}$ at $37^{\circ} \mathrm{C}$ for 20 minutes. Subsequently, slides were fixed in $4 \%$ formaldehyde in phosphate-buffered saline (PBS) for 10 minutes at room temperature and dehydrated in graded ethanol series. The PY353B probe, ${ }^{28}$ which hybridizes specifically to a series of repetitive sequences on the murine Y-chromosome, was nicktranslated in the presence of digoxigenin-11-dUTP using a commercial kit (DIG-Nick Translation Mix; Roche Diagnostics). Next, the digoxigeninlabeled Y-probe was denatured in $50 \%$ formamide/ $10 \%$ dextran sulfate/2 $\times$ sodium saline citrate buffer $(0.2 \mathrm{M} \mathrm{NaCl}, 30 \mathrm{mM}$ sodium citrate, $\mathrm{pH} 7.0)$ at $75^{\circ} \mathrm{C}$ for 5 minutes in the presence of salmon sperm DNA, and hybridized with sections at $37^{\circ} \mathrm{C}$ overnight $(30 \mathrm{ng} / \mathrm{slide})$. After washing with Trisbuffered saline (TBS; $50 \mathrm{mM}$ Tris, $0.05 \%$ Tween 20, pH 7.0), signals were detected using antidigoxigenin Fab conjugated with alkaline phosphatase followed by a nitroblue tetrazolium/5-bromo-4-chloro-indolyl-phosphatase substrate conversion (Rembrand RISH and AP Detection Kit; KREATECH Diagnostics, Amsterdam, The Netherlands). Finally, sections were counterstained for nuclear fast red. Positive hybridization of the Y-chromosome bearing cells was identified by the presence of a small, discrete area of blue precipitate in the nucleus.

To quantify the incorporation of EPCs in the allograft, successive slides containing adjacent sections were stained for CD31 as described earlier. Images were obtained on a Zeiss AxioPla 2 microscope at a $20 \times / 0.4$ magnification (Carl Zeiss). The percentage of Y-chromosome and CD31 double-positive cells was calculated manually by superposing pictures of both stainings on adjacent slides using KS300 software (Carl Zeiss).

\section{Statistical analysis}

Data are expressed as mean plus or minus SEM. Cholesterol values or the number of Flk-1 Sca-1 double-positive cells at different time points after gene transfer were compared with baseline values by one-way analysis of variance (ANOVA) followed by the Dunnett multiple comparisons test using Instat3 (GraphPad Software, San Diego, CA). Data of EPC functional assays and histologic parameters were compared by ANOVA followed by Tukey multiple comparisons test. When indicated, a logarithmic or square root transformation or nonparametric test was performed. A 2-way ANOVA to test interaction between the factor gene transfer and the factor bone marrow transplantation on intimal area in allografts was performed using Statistica (Statsoft Benelux, Groningen, The Netherlands). A 2-sided $P$ value of less than .05 was considered statistically significant.

\section{Results}

\section{SR-BI is expressed on EPCs}

To investigate whether effects of HDL on EPC biology may be mediated via scavenger receptor-BI, we first evaluated whether SR-BI is expressed on EPCs. Immunocytochemistry demonstrated SR-BI expression on both murine (data not shown) and human EPCs (Figure S1). No signal was detected in EPCs obtained from $\mathrm{SR}_{-B I^{-1-}}$ mice. FACS analysis showed SR-BI expression in $41 \%$ plus or minus $1.9 \%(n=4)$ of circulating Flk-1 Sca-1-positive cells obtained from wild-type mice.

\section{Human apo A-I gene transfer induces a persistent elevation of HDL cholesterol in chimeric C57BL/6 mice with $\mathrm{SR}-\mathrm{BI}^{+/+}$or $\mathrm{SR}-\mathrm{BI}^{-I-}$ bone marrow}

Persistent human apo A-I plasma levels (Figure 1A) resulted in a 2.0-fold $(P<.001)$ and 1.8 -fold $(P<.001)$ increase of HDL cholesterol at day 14 and day 35 , respectively, after transfer with $5 \times 10^{10}$ particles of AdA-I in C57BL/6 mice transplanted with $\mathrm{SR}-\mathrm{BI}^{+/+}$or SR-BI ${ }^{-/-}$bone marrow (Table 1). After human apo A-I transfer, human apo A-I containing HDL was polydisperse, and murine apo A-I levels decreased to less than $25 \%$ of baseline levels (data not shown). Gene transfer with the control vector Adnull, containing no expression cassette, did not result in a significant alteration of lipoprotein levels (Table 1). Lipoprotein profiles after transfer with AdA-I and Adnull are shown in Figure S2. 
A

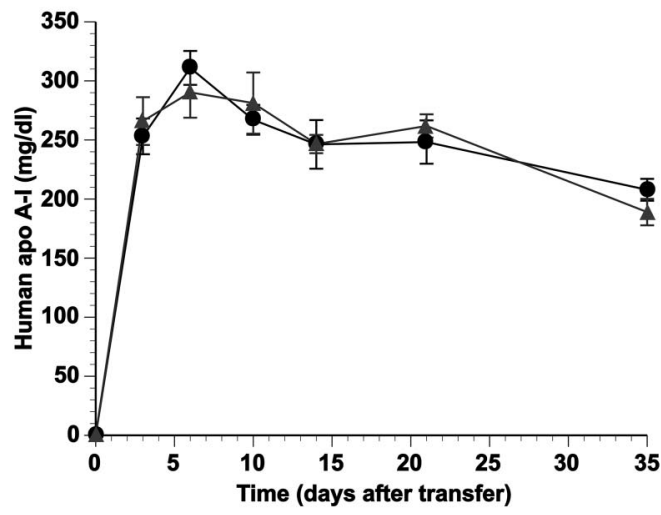

C

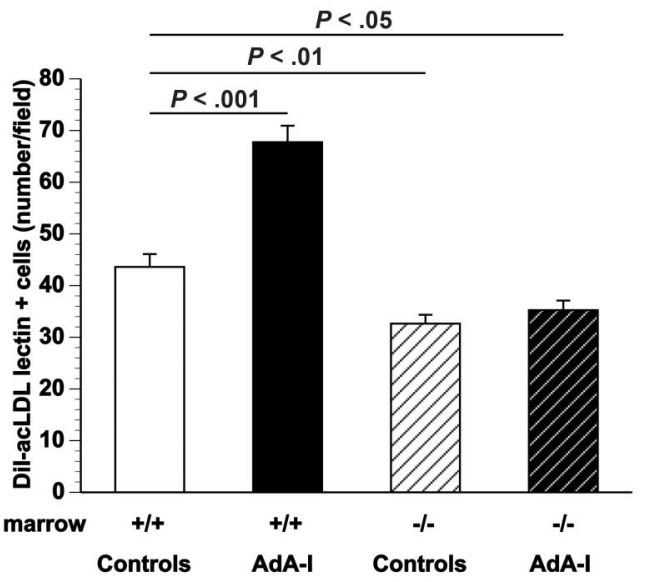

B

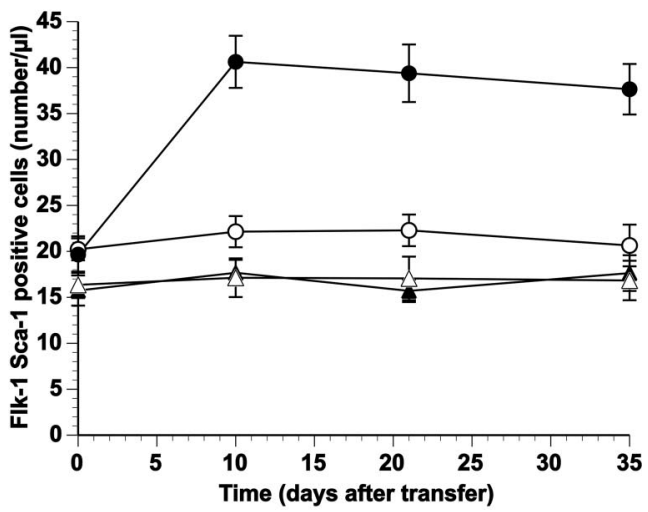

D

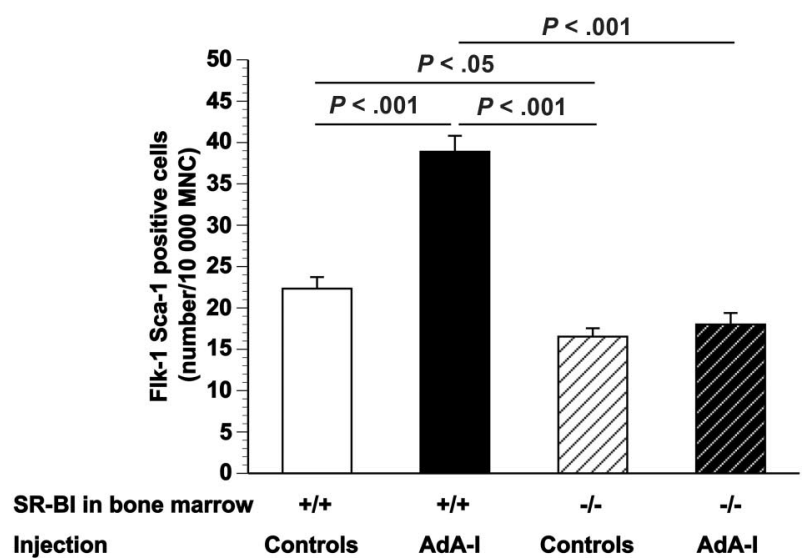

Figure 1. Human apo A-I gene transfer and EPC number in chimeric C57BL/6 SR-BI+/+ mice and chimeric C57BL/6 SR-BI-/- mice. (A) Human apo A-I expression levels after adenoviral gene transfer with $5 \times 10^{10}$ particles of $\mathrm{AdA}-\mathrm{I}$ in male C57BL/6 mice transplanted with SR-BI ${ }^{+/+}(\mathbf{0} ; \mathrm{n}=10)$ or SR-BI ${ }^{-/-}(\mathbf{\Delta} ; \mathrm{n}=10)$ bone marrow 4 weeks before gene transfer. (B) Time course of the number of Flk-1 Sca-1 double-positive cells in AdA-I $(\bullet, \mathbf{\Delta})-$ or Adnull $(\bigcirc, \triangle)$-treated C57BL/6 mice with SR-BI ${ }^{+/+}(\bullet, O)$ or SR-BI ${ }^{-1-}(\boldsymbol{\Lambda}, \triangle)$ bone marrow ( $n=10$ for each group). (C) Bar graph showing the number of Dil-acLDL FITC-isolectin double-positive cells after 7 days of ex vivo culture of bone marrow mononuclear cells isolated at day 35 after Adnull transfer or AdA-I transfer in C57BL/6 mice with SR-BI+/+ or SR-BI ${ }^{-/-}$bone marrow ( $\mathrm{n}=10$ for each group). (D) Bar graph showing the number of Flk-1 Sca-1 double-positive cells in the bone marrow of C57BL/6 mice with SR-BI ${ }^{+/+}$or SR-BI ${ }^{-/-}$bone marrow at day 35 after transfer with Adnull or AdA-I. Data are expressed as number/10 000 mononuclear cells (MNC) $(n=10$ for each group). Data are mean plus or minus SEM.

SR-BI deficiency in bone marrow lowers baseline EPC count and abrogates the increase of circulating EPCs induced by human apo A-I transfer in C57BL/6 mice

The number of Flk-1 Sca-1 double-positive cells in the peripheral blood at different time points after AdA-I transfer or Adnull transfer in C57BL/6 mice transplanted with $\mathrm{SR}-\mathrm{BI}^{+/+}$or SR-BI ${ }^{-/-}$ bone marrow is shown in Figure 1B. The baseline number of circulating Flk-1 Sca-1 double-positive cells was $25 \%(P<.01)$ lower in $\mathrm{C} 57 \mathrm{BL} / 6$ mice transplanted with $\mathrm{SR}-\mathrm{BI}^{-1-}$ bone marrow compared with mice transplanted with $\mathrm{SR}-\mathrm{BI}^{+/+}$bone marrow. Adnull gene transfer had no effect on the number of circulating Flk-1 Sca-1 double-positive cells at any time point. After AdA-I transfer, the number of circulating Flk-1 Sca-1 ${ }^{+}$cells increased 2.0-fold $(P<.001)$ at different time points after transfer in mice transplanted with $\mathrm{SR}-\mathrm{BI}^{+/+}$bone marrow, whereas no change

Table 1. Total cholesterol, non-HDL cholesterol, and HDL cholesterol plasma levels at baseline and at different time points after gene transfer with $5 \times 10^{10}$ particles of AdA-I or Adnull in C57BL/6 mice transplanted with $\mathrm{SR}-\mathrm{BI}^{+/+}$or SR-BI ${ }^{-/-}$bone marrow

\begin{tabular}{|c|c|c|c|c|c|c|}
\hline & \multicolumn{3}{|c|}{ SR-BI+/+ bone marrow } & \multicolumn{3}{|c|}{ SR-BI-I- bone marrow } \\
\hline & Baseline & Day 14 & Day 35 & Baseline & Day 14 & Day 35 \\
\hline \multicolumn{7}{|l|}{ AdA-I } \\
\hline Total cholesterol & $71 \pm 2.0$ & $140 \pm 3.1^{*}$ & $130 \pm 4.0^{*}$ & $70 \pm 2.7$ & $140 \pm 3.4^{\star}$ & $130 \pm 4.9^{*}$ \\
\hline Non-HDL cholesterol & $12 \pm 1.4$ & $26 \pm 0.90^{\star}$ & $22 \pm 1.2^{*}$ & $12 \pm 1.8$ & $27 \pm 1.0^{\star}$ & $23 \pm 1.4^{*}$ \\
\hline HDL cholesterol & $59 \pm 0.93$ & $120 \pm 2.2^{\star}$ & $100 \pm 3.0^{*}$ & $58 \pm 1.1$ & $120 \pm 2.4^{\star}$ & $110 \pm 3.6^{*}$ \\
\hline \multicolumn{7}{|l|}{ Adnull } \\
\hline Total cholesterol & $74 \pm 1.9$ & $72 \pm 3.0$ & $71 \pm 2.3$ & $71 \pm 2.6$ & $73 \pm 2.5$ & $71 \pm 2.7$ \\
\hline Non-HDL cholesterol & $14 \pm 1.4$ & $13 \pm 2.0$ & $12 \pm 1.5$ & $13 \pm 1.6$ & $14 \pm 1.7$ & $12 \pm 1.9$ \\
\hline HDL cholesterol & $60 \pm 0.79$ & $58 \pm 1.1$ & $59 \pm 0.97$ & $58 \pm 1.1$ & $60 \pm 0.83$ & $59 \pm 1.3$ \\
\hline
\end{tabular}

Non-HDL and HDL particles were separated by fast performance liquid chromatography gel filtration. Data are expressed in milligrams per deciliter and represent mean plus or minus SEM ( $n=10$ mice for each experimental condition).

${ }^{*} P<.001$ for comparison of different time points after transfer with baseline values. 
From www.bloodjournal.org at kuleuven on October 29, 2009. For personal use only.

A

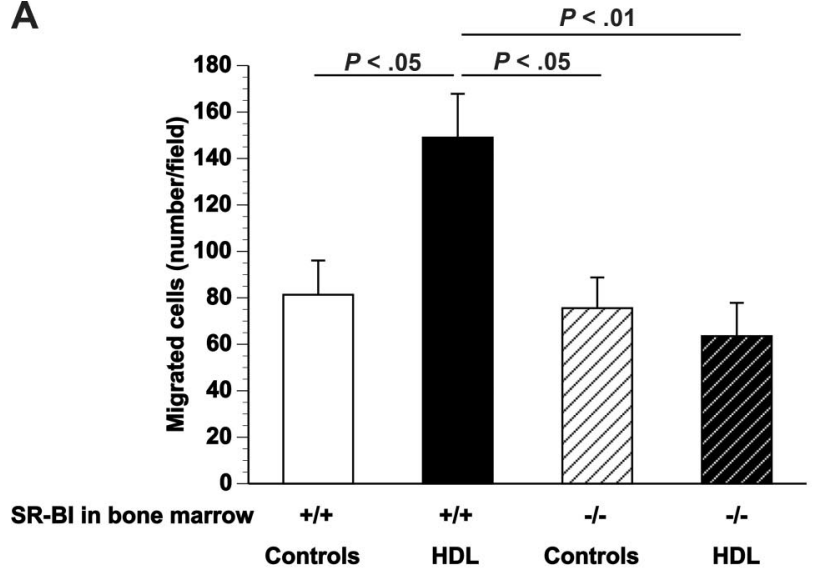

C

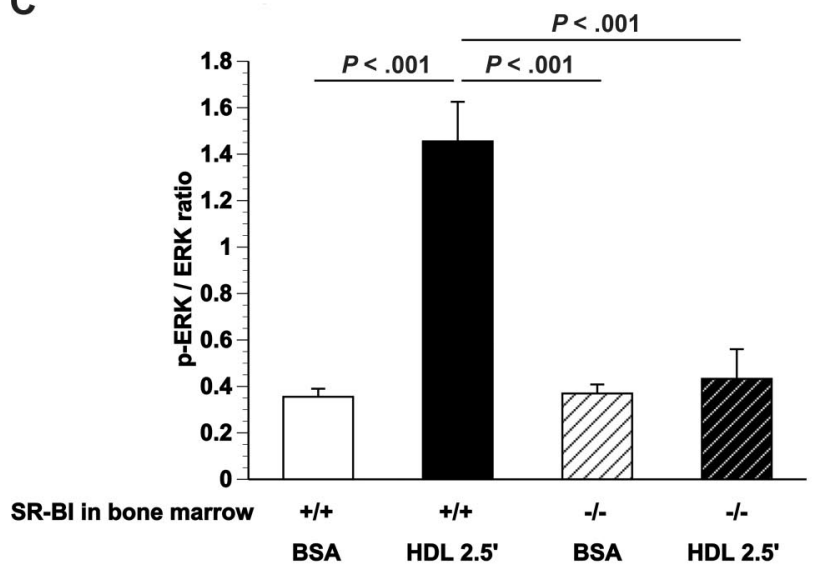

E

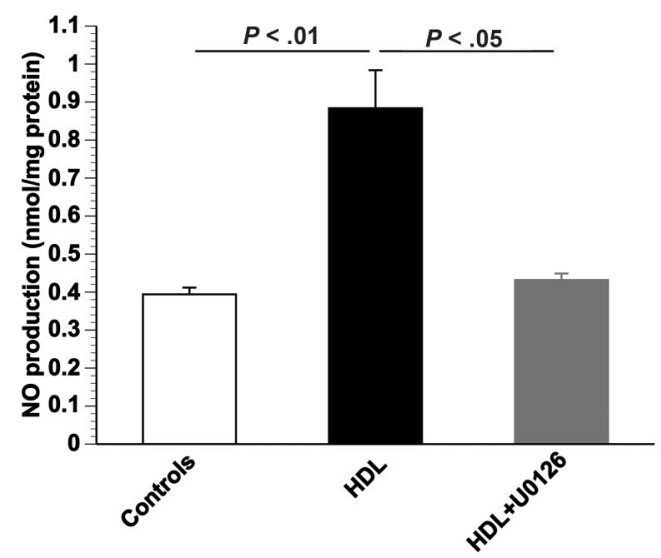

B

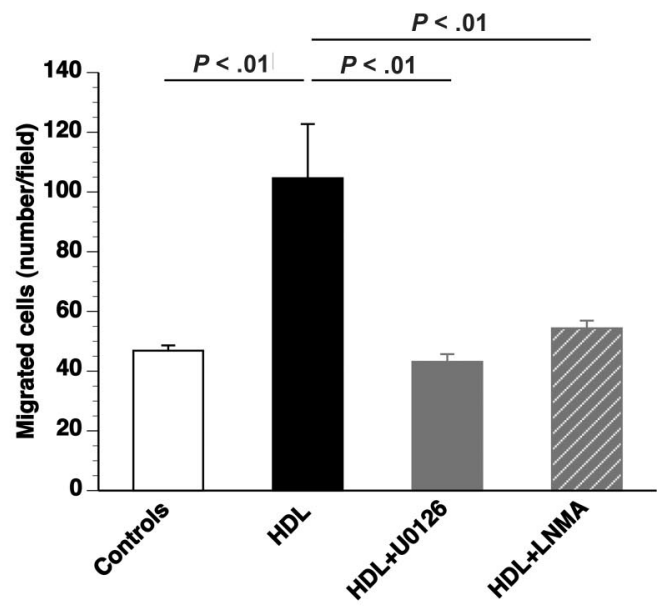

D

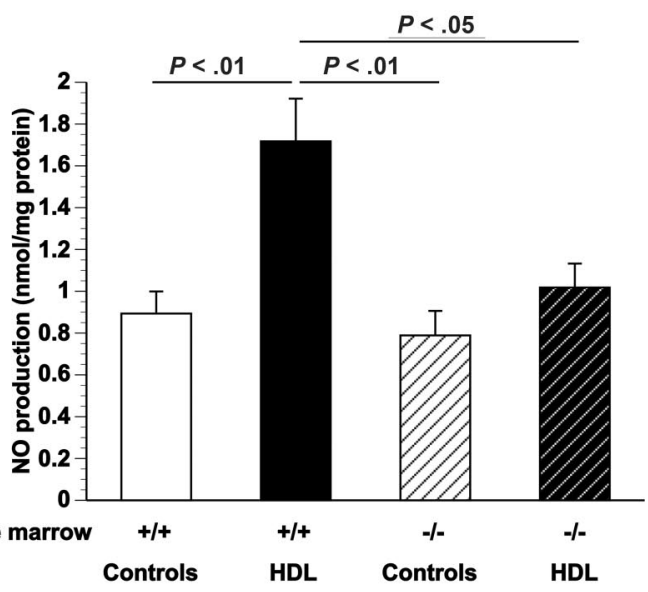

$\mathbf{F}$

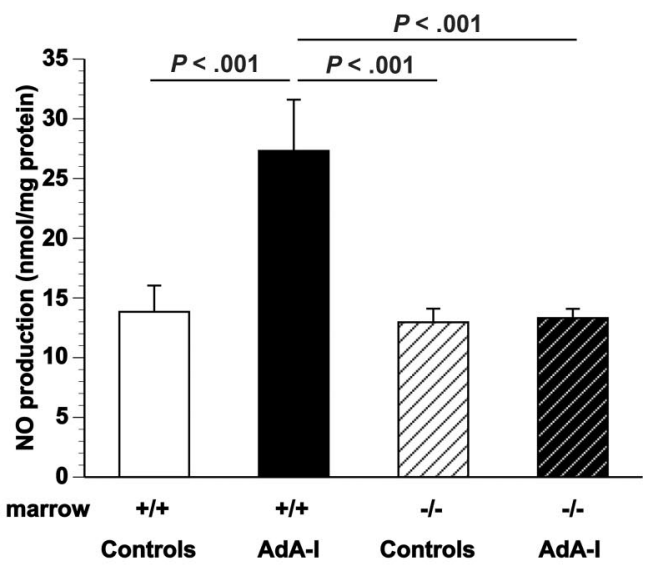

Figure 2. SR-BI and signal transduction induced by HDL in EPCs. (A) Bar graph showing the number of migrated EPCs in modified Boyden chambers. After 7 days of culture, bone marrow EPCs isolated from control mice or AdA-I-treated C57BL/6 mice with SR-BI ${ }^{+/+}$or SR-BI ${ }^{-/-}$bone marrow were seeded in the upper chamber. The lower chamber was supplemented with either $\mathrm{HDL}(100 \mu \mathrm{g} / \mathrm{mL})$ or an equivalent amount of bovine serum albumin and the number of migrated cells per microscopy field was quantified after 5 hours ( $n=4$ for each group). (B) Bar graph showing the number of migrated EPCs in modified Boyden chambers. After 7 days of culture, EPCs isolated from chimeric SR-BI+/+ C57BL/6 mice $(n=6)$ were seeded in the upper chamber. The lower chamber was supplemented with either bovine serum albumin $(100 \mu \mathrm{g} / \mathrm{mL})$ or $\mathrm{HDL}(100 \mu \mathrm{g} / \mathrm{mL})$. To inhibit ERK signaling and NO synthase activity, experiments were performed in the presence of U0126 (10 $\mu \mathrm{M})$ and LNMA $(2 \mathrm{mM})$, respectively. The number of migrated cells per microscopy field was quantified after 5 hours $(n=6$ for each group). (C) p-ERK/ERK ratio determined by Western blot. After 7 days of culture, bone marrow EPCs isolated from SR-BI ${ }^{+/+}$or SR-BI ${ }^{-1-}$ mice were exposed to either bovine serum albumin (100 $\mu \mathrm{g} / \mathrm{mL}$ ) or $\mathrm{HDL}$ $(100 \mu \mathrm{g} / \mathrm{mL}$ ) for 2.5 minutes $(\mathrm{n}=4$ for each group). (D) NO production in cultured bone marrow EPCs. After 7 days of culture, bone marrow EPCs isolated from SR-BI ${ }^{+/+}$or SR-BI ${ }^{-I-}$ mice were exposed to either bovine serum albumin $(100 \mu \mathrm{g} / \mathrm{mL}$ ) or HDL $(100 \mu \mathrm{g} / \mathrm{mL})$ for 24 hours, and NO production (nanomoles per milligram of protein) was measured ( $n=5$ for each group). (E) NO production in cultured EPCs. After 7 days of culture, EPCs isolated from chimeric SR-BI $/+C 57 B L / 6$ mice $(n=4)$ were exposed to either bovine serum albumin $(100 \mu \mathrm{g} / \mathrm{mL})$ or HDL $(100 \mu \mathrm{g} / \mathrm{mL})$. To inhibit ERK signaling, experiments were performed in the presence of U0126 $(10 \mu \mathrm{M})$. NO production (nanomoles per milligram of protein) was determined $(\mathrm{n}=4$ for each group). ( $\mathrm{F})$ NO production in the bone marrow at day 35 after transfer with Adnull or saline (Controls) or AdA-I in C57BL/6 mice with SR-BI ${ }^{+/+}\left(n=8\right.$ for each group) or SR-BI ${ }^{-/-}$bone marrow $(n=18$ for each group). Data are mean plus or minus SEM. 
Table 2. Morphometric analysis of allografts at day 21 after transplantation

\begin{tabular}{|c|c|c|c|c|}
\hline & \multicolumn{2}{|c|}{ SR-BII ${ }^{++}$bone marrow } & \multicolumn{2}{|c|}{ SR-BI ${ }^{-l-}$ bone marrow } \\
\hline & Controls & AdA-I & Controls & AdA-I \\
\hline No. of mice & 18 & 21 & 14 & 17 \\
\hline Area within the external elastic lamina & $150 \pm 9.9$ & $140 \pm 8.1$ & $140 \pm 10$ & $150 \pm 8.5$ \\
\hline Area within the internal elastic lamina & $89 \pm 7.2$ & $78 \pm 4.7$ & $94 \pm 9.2$ & $87 \pm 4.9$ \\
\hline Medial area & $66 \pm 4.0$ & $62 \pm 4.6$ & $55 \pm 4.7$ & $59 \pm 5.0$ \\
\hline Intimal area & $70 \pm 8.2$ & $19 \pm 2.7^{*}$ & $61 \pm 8.5 \dagger$ & $58 \pm 9.1 \dagger$ \\
\hline Luminal area & $19 \pm 5.2$ & $59 \pm 5.3^{*}$ & $33 \pm 8.6 \ddagger$ & $29 \pm 6.3 \S$ \\
\hline$\%$ stenosis & $78 \pm 5.4$ & $25 \pm 3.9^{*}$ & $66 \pm 7.0 \dagger$ & $64 \pm 7.6 \dagger$ \\
\hline
\end{tabular}

C57BL/6 mice were transplanted with SR-BI ${ }^{+/+}$or SR-BI ${ }^{-/-}$bone marrow and injected 14 days before transplantation with the control vector Adnull or saline (Controls) or a human apo A-I-expressing adenoviral vector (AdA-I). Morphometric data are expressed in $10^{3} \mu \mathrm{m}^{2}$ and represent mean plus or minus SEM. The percentage stenosis is defined as the intimal area divided by the area within the internal elastical lamina multiplied by 100 (\%).

${ }^{*} P<.001$ vs $\mathrm{SR}-\mathrm{BI}^{+/+}$bone marrow controls.

$\dagger P<.001$ vs SR-BI ${ }^{+/+}$bone marrow AdA-I.

$\ddagger P<.05$ vs $\mathrm{SR}-\mathrm{BI}^{+/+}$bone marrow AdA-I.

$\S P<.01$ vs $\mathrm{SR}-\mathrm{BI}^{+/+}$bone marrow AdA-I.

occurred in mice transplanted with $\mathrm{SR}-\mathrm{BI}^{-/-}$bone marrow. The number of DiI-acLDL FITC-isolectin double-positive cells after 7 days of ex vivo culture of bone marrow mononuclear cells isolated at day 35 after Adnull transfer (Figure 1C) was 1.3 -fold $(P<.01)$ lower in mice transplanted with $\mathrm{SR}-\mathrm{BI}^{-1-}$ bone marrow than in mice transplanted with $\mathrm{SR}-\mathrm{BI}^{+/+}$bone marrow. A phenotypic characterization of cultured EPCs is described in Document S1. The EPC number in the bone marrow after AdA-I transfer was 1.6-fold $(P<.001)$ higher than after Adnull transfer in mice transplanted with wild-type bone marrow, whereas no significant difference was observed in mice transplanted with $\mathrm{SR}-\mathrm{BI}^{-1-}$ bone marrow. These data were confirmed by quantification of the number of Flk-1 Sca- $1^{+}$cells in the bone marrow (Figure 1D).

\section{The effect of HDL on EPC function requires signaling via SR-BI and extracellular signal-regulated kinases and is dependent on NO}

To evaluate whether SR-BI deficiency not only affects EPC number in vivo but also EPC function, migration was quantified in vitro for cultured SR-BI ${ }^{+/+}$and SR-BI ${ }^{-/-}$bone marrow EPCs. Migration in the presence of $100 \mu \mathrm{g} / \mathrm{mL}$ HDL was 1.8 -fold $(P<.05)$ higher for $\mathrm{SR}_{-\mathrm{BI}}{ }^{+/+} \mathrm{EPCs}$, whereas no effect was observed for $\mathrm{SR}-\mathrm{BI}^{-/-}$ EPCs (Figure 2A). These results were confirmed using cultured EPCs derived from Sca- $1^{+}$isolated cells (Document S1; Figure S3). To investigate whether the effect of HDL on EPC migration requires signaling via ERKs and depends on NO, the effect of HDL on migration of SR-BI ${ }^{+/+}$EPCs was studied in the presence of the MEK1 and MEK2 inhibitor U0126 or the NO synthase inhibitor LNMA. U0126 as well as LNMA abrogated the stimulation of EPC migration by HDL (Figure 2B). In agreement, Western blot analysis indicated that the $\mathrm{p}$-ERK/ERK ratio increased 4.1-fold $(P<.001)$, 2.5 minutes after the addition of $100 \mu \mathrm{g} / \mathrm{mL} \mathrm{HDL}$ to $\mathrm{SR}-\mathrm{BI}^{+/+}$ EPCs (Figure 2C). In contrast, the p-ERK/ERK ratio was not significantly altered by addition of HDL to EPCs obtained from $\mathrm{SR}_{-\mathrm{BI}^{-/-}}$mice (Figure 2C). Figure 2D shows that NO production in cultured SR-BI ${ }^{+/+}$EPCs was increased 1.8 -fold $(P<.001)$ by addition of HDL. HDL did not result in increased NO production in cultured SR-BI ${ }^{-1-}$ EPCs (Figure 2D). Addition of HDL to cultured SR-BI ${ }^{+/+}$EPCs did not increase NO production in the presence of U0126 (Figure 2E). Taken together, these data indicate that the effect of HDL on EPC migration is mediated via NO and that enhanced NO production requires signaling via SR-BI and ERK. Increased NO production was also observed after human apo A-I transfer in vivo. AdA-I transfer enhanced NO production 2.0-fold $(P<.05)$ in the bone marrow of C57BL/6 mice transplanted with
SR-BI ${ }^{+/+}$bone marrow but not in mice with $\mathrm{SR}_{-} \mathrm{BI}^{-/-}$bone marrow (Figure $2 \mathrm{~F}$ ). The increased $\mathrm{NO}$ production in the bone marrow of chimeric $\mathrm{SR}_{-} \mathrm{BI}^{+/+}$mice may stimulate EPC mobilization.

\section{SR-BI deficiency in bone marrow abrogates the inhibitory effect of human apo A-I transfer on allograft vasculopathy in C57BL/6 mice}

Based on the observation that the effect of human apo A-I transfer on EPC number and function requires the expression of SR-BI in bone marrow cells, we evaluated a potential interaction between human apo A-I gene transfer and SR-BI expression in bone marrow cells in a murine model of transplantation arteriosclerosis. A 2-way ANOVA to test interaction between the factor gene transfer and the factor bone marrow transplantation on intimal area indicated that the interaction term is significant $(P<.002)$. Human apo A-I transfer 2 weeks before artery transplantation reduced intimal area at day 213.7 -fold $(P<.001)$ in mice reconstituted with $\mathrm{SR}-\mathrm{BI}^{+/+}$ bone marrow but had no effect in mice with $\mathrm{SR}-\mathrm{BI}^{-/-}$bone marrow (Table 2). No significant difference in intimal area was observed between control mice with $\mathrm{SR}-\mathrm{BI}^{+/+}$bone marrow and control mice with $\mathrm{SR}-\mathrm{BI}^{-/-}$bone marrow. Representative sections of neointima formation at day 21 after transfer in control and AdA-I-treated mice with SR-BI ${ }^{+/+}$or $\mathrm{SR}-\mathrm{BI}^{-/-}$bone marrow are shown in Figure 3.

\section{SR-BI deficiency in bone marrow abrogates potentiation of endothelial regeneration and EPC incorporation induced by human apo A-I transfer in allografts}

Endothelial regeneration was enhanced after AdA-I transfer in mice with $\mathrm{SR}-\mathrm{BI}^{+/+}$bone marrow as evidenced by a 3.0-fold $(P<.001)$ higher number of $\mathrm{CD} 31^{+}$endothelial cells lining the lumen compared with control mice with $\mathrm{SR}-\mathrm{BI}^{+/+}$bone marrow (Figure 4A). In contrast, AdA-I transfer had no effect on endothelial regeneration in mice with $\mathrm{SR}-\mathrm{BI}^{-/-}$bone marrow (Figure 4A). To evaluate whether SR-BI expression in bone marrow-derived cells affects EPC incorporation after human apo A-I transfer, bone marrow transplantations were performed with male $\mathrm{SR}-\mathrm{BI}^{+/+}$or $\mathrm{SR}_{-} \mathrm{BI}^{-1-}$ bone marrow into female $\mathrm{C} 57 \mathrm{BL} / 6$ mice, and artery transplantation was performed with arteries from female BALB/c donors ( $n=8$ for each experimental group). In situ hybridization was performed for the murine Y-chromosome, and the number of CD31 Y-chromosome-positive cells was quantified 21 days after transplantation. This number was increased 9.7 -fold $(P<.001)$ in 
Figure 3. Effect of human apo A-I transfer on allograft vasculopathy in chimeric $\mathrm{C} 57 \mathrm{BL} / 6 \mathrm{SR}-\mathrm{BI}^{+/+}$mice and chimeric C57BL/6 SR-BI-I- mice. Representative sections of allograft vasculopathy at day 21 after transplantation in control $(A, C)$ and $A d A-I(B, D)$-treated C57BL/6 mice with $\mathrm{SR}-\mathrm{BI}^{+/+}(\mathrm{A}, \mathrm{B})$ or $\mathrm{SR}-\mathrm{BI}^{-/-}(\mathrm{C}, \mathrm{D})$ bone marrow.
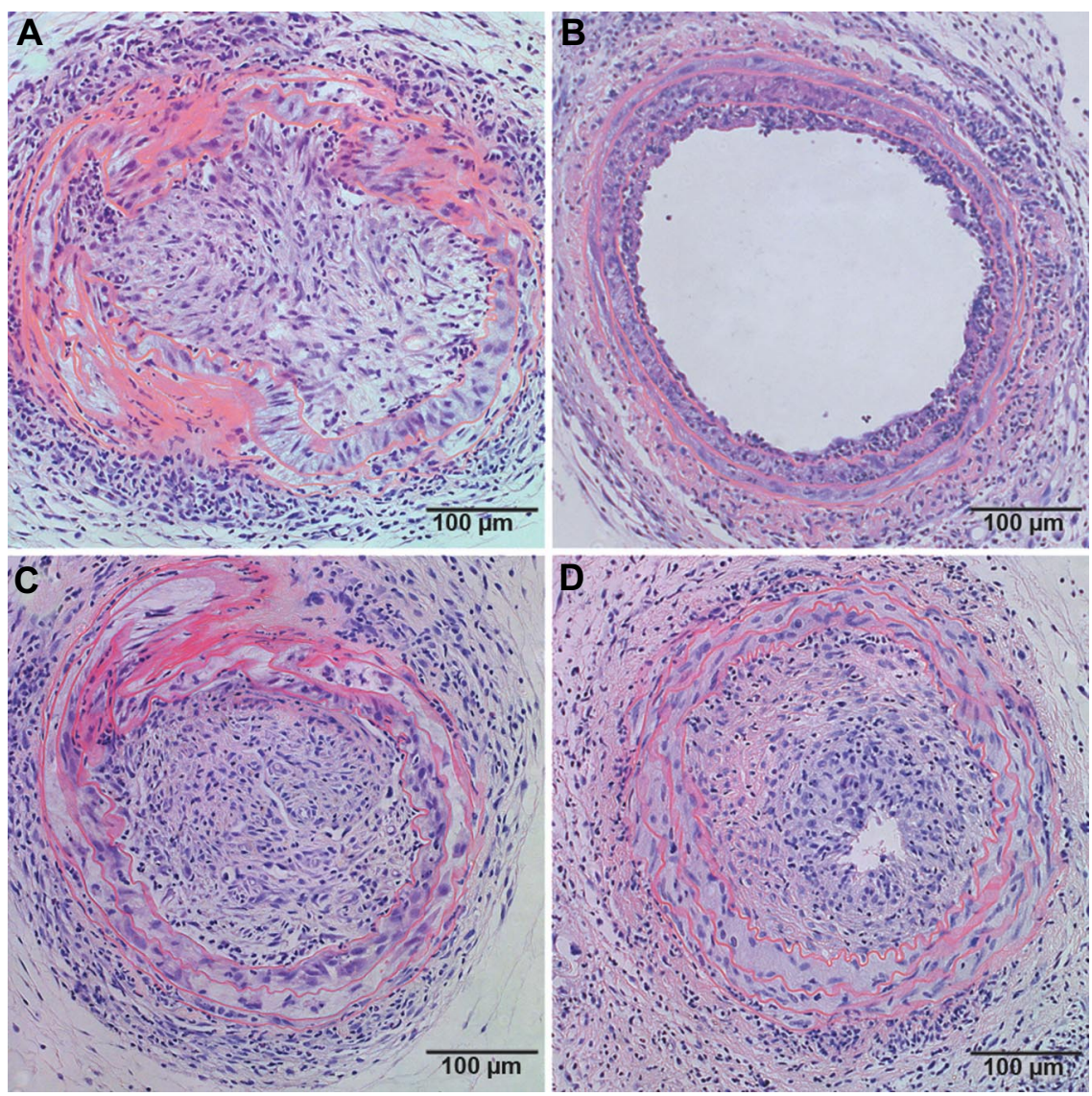

AdA-I-treated chimeric SR-BI ${ }^{+/+}$mice, whereas no effect was observed after AdA-I transfer in chimeric SR-BI ${ }^{-/-}$mice (Figure 4B), indicating that EPC incorporation requires SR-BI expression in bone marrow and bone marrow-derived cells. The percentage of CD31 Y-chromosome-positive cells increased 4.7-fold $(P<.001)$ after AdA-I transfer in chimeric SR-BI ${ }^{+/+}$mice $(35 \% \pm 3.0 \%$ vs $7.4 \% \pm 2.2 \%$ ), whereas no change was observed in chimeric $\mathrm{SR}-\mathrm{BI}^{-1-}$ mice $(4.9 \% \pm 2.4 \%$ vs $5.0 \% \pm 1.4 \%)$.

\section{Increased HDL cholesterol after human apo A-I transfer attenuates inflammation in allografts in chimeric $\mathrm{SR}-\mathrm{BI}^{+/+}$mice but not in chimeric SR-BI-I- mice}

HDL exerts anti-inflammatory effects on the endothelium. ${ }^{29} \mathrm{We}$ evaluated whether enhanced endothelial regeneration in chimeric SR-BI ${ }^{+/+}$mice after human apo A-I transfer was associated with reduced allograft inflammation. Table 3 shows that AdA-I gene transfer significantly reduced leukocyte and macrophage infiltration (Figure S4) at day 21 after artery transplantation in mice with
$\mathrm{SR}-\mathrm{BI}^{+/+}$bone marrow but not in mice with $\mathrm{SR}-\mathrm{BI}^{-/-}$bone marrow.

\section{Discussion}

The main findings of this study are that (1) the effect of increased HDL cholesterol after human apo A-I transfer on EPC number and function requires SR-BI expression in bone marrow and bone marrow-derived cells; (2) accelerated endothelial regeneration, increased EPC incorporation, and attenuation of allograft vasculopathy induced by hepatocyte-directed human apo A-I transfer in a murine model of transplantation arteriosclerosis are strictly dependent on SR-BI expression in bone marrow and bone marrowderived cells; and (3) the effect of HDL on EPC migration in vitro is mediated via NO, and enhanced NO production requires signaling via SR-BI and ERK. Taken together, the current study shows the crucial role of SR-BI-expressing bone marrow-derived
A

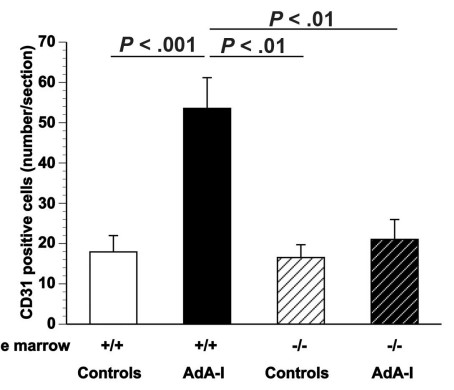

B

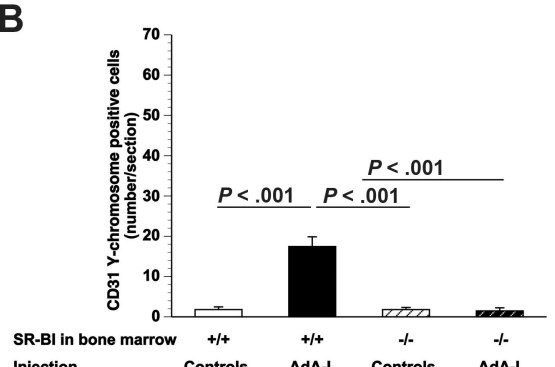

Figure 4. Effect of human apo A-I transfer on endothelial regeneration and EPC incorporation in chimeric C57BL/6 SR-BI ${ }^{+/+}$mice and chimeric C57BL/6 SR$\mathrm{BI}^{-1-}$ mice. The effect of AdA-I transfer on endothelial cell regeneration in allografts is dependent on SR-BI expression in bone marrow-derived cells. (A) Bar graph showing the number of $\mathrm{CD} 31^{+}$endothelial cells at day 21 after artery transplantation in control and AdA-I-treated C57BL/6 mice with $\mathrm{SR}-\mathrm{BI}^{+/+}$or $\mathrm{SR}-\mathrm{BI}^{-/-}$bone marrow. (B) Bar graph showing the number of CD31 Y-chromosome-positive endothelial cells at day 21 after artery transplantation in control and AdA-I-treated C57BL/6 mice with $\mathrm{SR}-\mathrm{BI}^{+/+}$or SR-BI ${ }^{-/-}$bone marrow. Data are mean plus or minus SEM. 
Table 3. Immunohistochemical analysis of allograft inflammation at day 21 after transplantation

\begin{tabular}{lccccc}
\hline & \multicolumn{2}{c}{ SR-BI ${ }^{+/+}$bone marrow } & & \multicolumn{2}{c}{ SR-BI-l- bone marrow } \\
\cline { 2 - 3 } \cline { 6 - 7 } & Controls & AdA-I & & Controls & AdA-I \\
\hline Leukocytes & $59 \pm 3.2$ & $42 \pm 3.2^{*}$ & & $56 \pm 2.6 \dagger$ & $63 \pm 3.7 \ddagger$ \\
Macrophages & $51 \pm 3.7$ & $33 \pm 3.1^{*}$ & & $53 \pm 3.8 \S$ & $48 \pm 4.0 \dagger$ \\
T lymphocytes & $10 \pm 1.3$ & $8.0 \pm 1.2$ & & $7.1 \pm 0.93$ & $8.1 \pm 2.1$ \\
\hline
\end{tabular}

Data are expressed in percentage of the total number of cells in the intimal area and represent mean \pm SEM. The number of mice in each group is identical as in Table 2 .

${ }^{*} P<.01$ vs SR $-\mathrm{BI}^{+/+}$bone marrow controls.

$\dagger P<.05$ vs $\mathrm{SR}-\mathrm{BI} \mathrm{I}^{+/+}$bone marrow AdA-I.

$\ddagger P<.001$ vs $\mathrm{SR}-\mathrm{BI}^{+/+}$bone marrow $\mathrm{AdA}-\mathrm{I}$.

$\S P<.01$ vs $\mathrm{SR}-\mathrm{BI}^{+/+}$bone marrow $\mathrm{AdA}-\mathrm{I}$.

EPCs in the protective effect of increased HDL cholesterol induced by overexpression of human apo A-I on allograft vasculopathy in mice.

Bone marrow transplantations with $\mathrm{SR}-\mathrm{BI}^{-/-}$or $\mathrm{SR}-\mathrm{BI}^{+/+}$bone marrow were a cornerstone in the design of experiments to unravel the mechanistic link between the effect of human apo A-I transfer on EPC biology and on allograft vasculopathy. We cannot exclude that part of the effects of increased HDL cholesterol on bone marrow-derived EPCs are mediated indirectly via cargo molecules of SR-BI-bound HDL, like sphingosine-1-phosphate (S1P). ${ }^{30,31}$ $\mathrm{S} 1 \mathrm{P}$ receptor $1\left(\mathrm{~S}_{1} \mathrm{P}_{1}\right)$ and $\mathrm{S} 1 \mathrm{P}$ receptor $3\left(\mathrm{~S}_{1} \mathrm{P}_{3}\right)$ are expressed on EPCs. ${ }^{32}$ The $\mathrm{S}_{1} \mathrm{P}_{3}$ receptor has been shown to mediate the stimulation of the functional capacity of progenitor cells by S1P. ${ }^{32}$ Regardless of the potential involvement of S1P receptors, our data conclusively demonstrate that SR-BI is strictly required for the effects of human apo A-I transfer on EPC biology. Reconstituted HDL, containing no S1P, has been shown to promote the differentiation of human peripheral mononuclear cells to EPCs. ${ }^{33}$ In light of this observation, our results suggest that SR-BI may be sufficient for HDL-mediated effects on EPCs.

EPC mobilization from the bone marrow requires increased bone marrow NO levels. ${ }^{34}$ In the current study, we show that human apo A-I transfer resulted in increased NO production in the bone marrow of C57BL/6 mice transplanted with $\mathrm{SR}-\mathrm{BI}^{+/+}$bone marrow but not in mice transplanted with $\mathrm{SR}-\mathrm{BI}^{-1-}$ bone marrow. Increased EPC mobilization is probably a major factor in the increase of EPC number in the peripheral blood after human apo A-I transfer. In addition, EPC numbers are increased after AdA-I transfer in the bone marrow of chimeric SR-BI ${ }^{+/+}$but not in chimeric SR-BI ${ }^{-1-}$ mice. Our data suggest that a direct action of HDL in the bone marrow is an essential effector in the HDLinduced attenuation of allograft vasculopathy.

EPC incorporation experiments demonstrate that SR-BI expression in EPCs is required to observe enhanced incorporation after human apo A-I transfer. These in vivo experimental results are in line with our in vitro data showing that enhanced EPC migration requires SR-BI and ERK signaling and is dependent on NO. In $\mathrm{CHO}$ cells, it has been demonstrated that HDL signaling via SR-BI involves protein kinase $\mathrm{C}$-independent activation of Ras, which is completely blocked by pertussis toxin, thus implicating heterotrimeric G proteins. ${ }^{35}$ Subsequent phosphorylation of Raf-1 and MEK1 results in phosphorylation and activation of ERK. ${ }^{36-38}$ ERK $1 / 2$ directly phosphorylate endothelial NO synthase (eNOS) in endothelial cells. ${ }^{39}$ Phosphorylation and activation of eNOS and production of NO in turn contribute to ERK activation and increased NO production through a positive feed-forward mechanism. ${ }^{39}$ The role of NO in the effects of HDL is in line with its role in the beneficial effects of statin therapy, erythropoietin, and physical exercise on EPC biology. 6,40,41

EPC number in the bone marrow and in the peripheral circulation was slightly reduced in chimeric $\mathrm{SR}_{-} \mathrm{BI}^{-/-}$mice compared with chimeric SR-BI ${ }^{+/+}$mice. No significant differences of EPC incorporation, endothelial regeneration, and allograft vasculopathy were observed between control chimeric SR-BI ${ }^{+/+}$ mice and control chimeric SR-BI ${ }^{-1-}$ mice. These results suggest that a threshold exists to observe augmented EPC incorporation and accelerated endothelial regeneration by HDL. This threshold is not reached at endogenous murine apo A-I-containing HDL concentrations, and supraphysiologic levels of human apo A-Icontaining HDL are required to overcome this threshold. In contrast, carotid artery reendothelialization after perivascular electric injury has been shown to be blunted in $\mathrm{SR}_{-} \mathrm{BI}^{-1-}$ mice compared with wild-type mice, suggesting an effect of endogenous HDL levels on endothelial regeneration in this model. ${ }^{16} \mathrm{We}$ speculate that the relative contribution of EPCs to endothelial regeneration in the paratopic transplantation model is significantly higher than in the model of perivascular injury. This may be the result of continuing immunologic insult against donor-derived endothelial cells and the isogeneic nature of recipient EPC-derived endothelial cells in allografts. Endogenous HDL may be sufficient for endothelial regeneration mediated by SR-BI-expressing adjacent endothelial cells in the model of perivascular injury. In contrast, supraphysiologic levels of human apo A-I-containing HDL appear to be required for accelerated EPC-mediated endothelial regeneration in the transplantation model. This is in line with reports showing that administration of exogenous reconstituted HDL increases the recruitment of EPCs into the aortic endothelium after endothelial damage induced by lipopolysaccharide in C57BL/6 mice ${ }^{42}$ and enhances the contribution of bone marrow-derived cells to neovascularization in a mouse hindlimb ischemia model. ${ }^{33}$ Because an HDL concentration gradient exists between blood plasma and bone marrow plasma, SR-BI-mediated effects on endothelial cells may occur at lower HDL levels than SR-BI-mediated effects in the bone marrow. Because our data show that human apo A-I-containing HDL increases EPC number in the bone marrow and may enhance EPC mobilization from the bone marrow, this action may require higher circulating HDL levels. EPCs may not only directly contribute to accelerated endothelial regeneration by incorporation in the endothelium but also indirectly by paracrine effects on endothelial cells. ${ }^{43}$ Because incorporating EPCs only partially account for the increase in endothelial cell number after AdA-I transfer in chimeric SR-BI ${ }^{+/+}$mice, this strongly suggests that the paracrine action of bone marrow-derived cells on endothelial regeneration is also enhanced by HDL in an SR-BI-dependent pathway.

Allograft inflammation was reduced after human apo A-I transfer in mice transplanted with wild-type bone marrow but not in mice transplanted with $\mathrm{SR}-\mathrm{BI}^{-/-}$bone marrow. This reduced allograft inflammation is probably the result of improved endothelial regeneration and endothelial function. ${ }^{29}$ However, we cannot exclude that HDL is having direct effects on inflammatory cells via SR-BI that may have contributed to the attenuation of allograft vasculopathy.

In conclusion, the current study shows that the protective effect of hepatocyte-directed human apo A-I transfer on allograft vasculopathy requires SR-BI expression in bone marrow and bone marrow-derived cells. HDL modulates EPC biology via SR-BI. The action of HDL on bone marrow-derived EPCs appears to be a critical effector of a therapeutic HDL raising intervention in a murine model of allograft vasculopathy. 


\section{Acknowledgments}

The authors thank J. Hendrix and Z. Zhang for excellent technical assistance.

This work was supported by the Fonds voor Wetenschappelijk Onderzoek-Vlaanderen (grant G.0564.05). The Center for Molecular and Vascular Biology is supported by Excellentiefinanciering Katholieke Universiteit (KU) Leuven (EF/05/013). M.v.E. is an Established Investigator of the Netherlands Heart Foundation (grant 2007T056). E.V.C. is a Research Assistant of the Fonds voor Wetenschappelijk Onderzoek-Vlaanderen. F.J. is a Research Assistant of the Instituut voor de Aanmoediging van Innovatie door Wetenschap en Technologie in Vlaanderen. M.T. is a Fellow of the Fonds voor Wetenschappelijk Onderzoek-Vlaanderen and is supported by a German Leibniz-Award (DFG 600/8-1).

\section{Authorship}

Contribution: Y.F., E.V.C., F.J., and V.C. acquired, analyzed, and interpreted the data; M.v.E. provided an essential animal model for the current study; M.E. acquired data and supervised research on in situ hybridization for the Y chromosome; and Y.F., S.V.L., M.T., and B.D.G. conceived and designed research. All authors made critical revision of the manuscript for important intellectual content.

Conflict-of-interest disclosure: The authors declare no competing financial interests.

Correspondence: Bart De Geest, Center for Molecular and Vascular Biology, University of Leuven, Campus Gasthuisberg, Herestraat 49, 3000 Leuven, Belgium; e-mail: bart.degeest@ med.kuleuven.be.

\section{References}

1. Taylor DO, Edwards LB, Boucek MM, et al. Registry of the International Society for Heart and Lung Transplantation: twenty-fourth official adult heart transplant report-2007. J Heart Lung Transplant. 2007;26:769-781.

2. Boucek MM, Aurora P, Edwards LB, et al. Registry of the International Society for Heart and Lung Transplantation: tenth official pediatric heart transplantation report-2007. J Heart Lung Transplant. 2007;26:796-807.

3. Weiss MJ, Madsen JC, Rosengard BR, Allan JS. Mechanisms of chronic rejection in cardiothoracic transplantation. Front Biosci. 2008;13: 2980-2988.

4. Behrendt D, Ganz P. Endothelial function: from vascular biology to clinical applications. Am J Cardiol. 2002;90:40L-48L.

5. Pinney SP, Mancini D. Cardiac allograft vasculopathy: advances in understanding its pathophysiology, prevention, and treatment. Curr Opin Cardiol. 2004;19:170-176.

6. Walter DH, Rittig K, Bahlmann FH, et al. Statin therapy accelerates reendothelialization: a novel effect involving mobilization and incorporation of bone marrow-derived endothelial progenitor cells. Circulation. 2002;105:3017-3024.

7. Werner N, Priller J, Laufs U, et al. Bone marrowderived progenitor cells modulate vascular reendothelialization and neointimal formation: effect of 3-hydroxy-3-methylglutaryl coenzyme a reductase inhibition. Arterioscler Thromb Vasc Biol. 2002;22:1567-1572.

8. Friedrich EB, Walenta K, Scharlau J, Nickenig G, Werner N. CD34-/CD133+/VEGFR-2+ endothelial progenitor cell subpopulation with potent vasoregenerative capacities. Circ Res. 2006;98: e20-e25.

9. Werner N, Junk S, Laufs U, et al. Intravenous transfusion of endothelial progenitor cells reduces neointima formation after vascular injury. Circ Res. 2003;93:e17-e24.

10. Hu Y, Davison F, Zhang Z, Xu Q. Endothelial replacement and angiogenesis in arteriosclerotic lesions of allografts are contributed by circulating progenitor cells. Circulation. 2003;108:31223127.

11. Feng $Y$, Jacobs F, Van Craeyveld E, et al. Human ApoA-I transfer attenuates transplant arteriosclerosis via enhanced incorporation of bone marrowderived endothelial progenitor cells. Arterioscler Thromb Vasc Biol. 2008;28:278-283.

12. Acton S, Rigotti A, Landschulz KT, Xu S, Hobbs $\mathrm{HH}$, Krieger M. Identification of scavenger receptor SR-BI as a high density lipoprotein receptor. Science. 1996;271:518-520.
13. Rigotti A, Miettinen HE, Krieger $M$. The role of the high-density lipoprotein receptor SR-BI in the lipid metabolism of endocrine and other tissues. Endocr Rev. 2003;24:357-387.

14. Fluiter K, van der Westhuijzen DR, van Berkel TJ. In vivo regulation of scavenger receptor $\mathrm{BI}$ and the selective uptake of high density lipoprotein cholesteryl esters in rat liver parenchymal and Kupffer cells. J Biol Chem. 1998;273:84348438.

15. Ji Y, Jian B, Wang N, et al. Scavenger receptor BI promotes high density lipoprotein-mediated cellular cholesterol efflux. J Biol Chem. 1997;272 20982-20985.

16. Seetharam D, Mineo C, Gormley AK, et al. High-density lipoprotein promotes endothelial cell migration and reendothelialization via scavenger receptor-B type I. Circ Res. 2006;98:6372.

17. Mineo C, Shaul PW. HDL stimulation of endothelial nitric oxide synthase: a novel mechanism of HDL action. Trends Cardiovasc Med. 2003;13: 226-231.

18. Rigotti A, Trigatti BL, Penman M, Rayburn $\mathrm{H}$, Herz J, Krieger M. A targeted mutation in the murine gene encoding the high density lipoprotein (HDL) receptor scavenger receptor class $B$ type I reveals its key role in HDL metabolism. Proc Natl Acad Sci U S A. 1997;94:1261012615.

19. Jacobs F, Snoeys J, Feng Y, et al. Direct comparison of hepatocyte-specific expression cassettes following adenoviral and nonviral hydrodynamic gene transfer. Gene Ther. 2008;15: 594-603.

20. Van Linthout S, Lusky M, Collen D, De Geest B. Persistent hepatic expression of human apo A-I after transfer with a helper-virus independent adenoviral vector. Gene Ther. 2002;9:15201528.

21. Shi C, Russell ME, Bianchi C, Newell JB, Haber E. Murine model of accelerated transplant arteriosclerosis. Circ Res. 1994;75:199-207.

22. Van Linthout S, Collen D, De Geest B. Effect of promoters and enhancers on expression, transgene DNA persistence, and hepatotoxicity after adenoviral gene transfer of human apolipoprotein A-I. Hum Gene Ther. 2002;13:829840.

23. Chapman MJ, Goldstein S, Lagrange D, Laplaud PM. A density gradient ultracentrifugal procedure for the isolation of the major lipoprotein classes from human serum. J Lipid Res. 1981;22:339358.

24. Sbaa E, Dewever J, Martinive P, et al. Caveolin plays a central role in endothelial progenitor cell mobilization and homing in SDF-1-driven postischemic vasculogenesis. Circ Res. 2006;98: 1219-1227.

25. Suda O, Tsutsui M, Morishita T, et al. Long-term treatment with $\mathrm{N}$ (omega)-nitro-L-arginine methy ester causes arteriosclerotic coronary lesions in endothelial nitric oxide synthase-deficient mice. Circulation. 2002;106:1729-1735.

26. Hu Y, Davison F, Ludewig B, et al. Smooth muscle cells in transplant atherosclerotic lesions are originated from recipients, but not bone marrow progenitor cells. Circulation. 2002;106:18341839.

27. Hu Y, Mayr M, Metzler B, Erdel M, Davison F, Xu $Q$. Both donor and recipient origins of smooth muscle cells in vein graft atherosclerotic lesions. Circ Res. 2002;91:e13-e20.

28. Bishop CE, Boursot P, Baron B, Bonhomme F, Hatat D. Most classical Mus musculus domesticus laboratory mouse strains carry a Mus musculus musculus Y chromosome. Nature. 1985;315: 70-72.

29. Cockerill GW, Rye KA, Gamble JR, Vadas MA, Barter PJ. High-density lipoproteins inhibit cytokine-induced expression of endothelial cell adhesion molecules. Arterioscler Thromb Vasc Biol. 1995;15:1987-1994.

30. Kimura T, Sato K, Kuwabara A, et al. Sphingosine 1-phosphate may be a major component of plasma lipoproteins responsible for the cytoprotective actions in human umbilical vein endothelial cells. J Biol Chem. 2001;276:3178031785 .

31. Kimura T, Sato K, Malchinkhuu E, et al. High-density lipoprotein stimulates endothelial cell migration and survival through sphingosine 1-phosphate and its receptors. Arterioscler Thromb Vasc Biol. 2003;23: 1283-1288.

32. Walter DH, Rochwalsky U, Reinhold J, et al. Sphingosine-1-phosphate stimulates the functional capacity of progenitor cells by activation of the CXCR4-dependent signaling pathway via the S1P3 receptor. Arterioscler Thromb Vasc Biol. 2007;27:275-282.

33. Sumi M, Sata M, Miura SI, et al. Reconstituted high-density lipoprotein stimulates differentiation of endothelial progenitor cells and enhances ischemia-induced angiogenesis. Arterioscler Thromb Vasc Biol. 2007;27:813-818.

34. Aicher A, Heeschen C, Mildner-Rihm C, et al. Essential role of endothelial nitric oxide synthase for mobilization of stem and progenitor cells. Nat Med. 2003;9:1370-1376.

35. Grewal T, de Diego I, Kirchhoff MF, et al. High 
From www.bloodjournal.org at kuleuven on October 29, 2009. For personal use only.

density lipoprotein-induced signaling of the MAPK pathway involves scavenger receptor type BI-mediated activation of Ras. J Biol Chem. 2003;278:16478-16481.

36. Deeg MA, Bowen RF, Oram JF, Bierman EL. High density lipoproteins stimulate mitogen-activated protein kinases in human skin fibroblasts. Arterioscler Thromb Vasc Biol. 1997;17:1667-1674.

37. Nofer JR, Junker R, Pulawski E, et al. High density lipoproteins induce cell cycle entry in vascular smooth muscle cells via mitogen activated protein kinase-dependent pathway. Thromb Haemost. 2001;85:730-735

38. Garver WS, Deeg MA, Bowen RF, Culala MM,
Bierman EL, Oram JF. Phosphoproteins regulated by the interaction of high-density lipoprotein with human skin fibroblasts. Arterioscler Thromb Vasc Biol. 1997;17:2698-2706.

39. Nguyen $\mathrm{A}, \mathrm{Cai} \mathrm{H}$. Netrin-1 induces angiogenesis via a DCC-dependent ERK1/2-eNOS feed-forward mechanism. Proc Natl Acad Sci U S A. 2006; 103:6530-6535.

40. Urao N, Okigaki M, Yamada H, et al. Erythropoietin-mobilized endothelial progenitors enhance reendothelialization via Akt-endothelial nitric oxide synthase activation and prevent neointimal hyperplasia. Circ Res. 2006;98:1405-1413.

41. d'Uscio LV, Smith LA, Santhanam AV, Richard- son D, Nath KA, Katusic ZS. Essential role of endothelial nitric oxide synthase in vascular effects of erythropoietin. Hypertension. 2007; 49:1142-1148.

42. Tso C, Martinic G, Fan WH, Rogers C, Rye KA, Barter PJ. High-density lipoproteins enhance progenitor-mediated endothelium repair in mice. Arterioscler Thromb Vasc Biol. 2006;26: 1144-1149.

43. Urbich C, Aicher A, Heeschen C, et al. Soluble factors released by endothelial progenitor cells promote migration of endothelial cells and cardiac resident progenitor cells. J Mol Cell Cardiol. 2005; 39:733-742 